$11-1-2005$

\title{
Arthropod diversity and allochthonous-based food webs on tiny oceanic islands
}

Lloyd W. Morrison

Missouri State University

Follow this and additional works at: https://bearworks.missouristate.edu/articles-cnas

\section{Recommended Citation}

Morrison, Lloyd W. "Arthropod diversity and allochthonous-based food webs on tiny oceanic islands." Diversity and Distributions 11, no. 6 (2005): 517-524.

This article or document was made available through BearWorks, the institutional repository of Missouri State University. The work contained in it may be protected by copyright and require permission of the copyright holder for reuse or redistribution.

For more information, please contact BearWorks@library.missouristate.edu. 


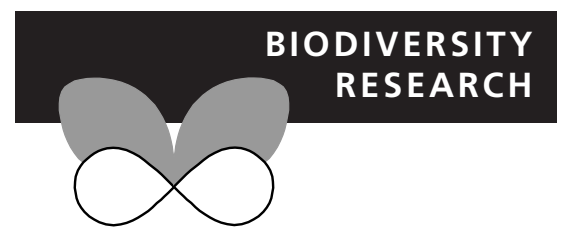

\title{
Arthropod diversity and allochthonous- based food webs on tiny oceanic islands
}

\author{
Lloyd W. Morrison
}

Department of Biology, Missouri State

University, 901 South National Avenue,

Springfield, MO 65804 USA
Correspondence: Lloyd W. Morrison, Department of Biology, Missouri State University, 901 South National Avenue, Springfield, MO 65804 USA. Fax: (417) 836 8886; E-mail: lloydmorrison@missouristate.edu

\begin{abstract}
Very small islands, on the order of a few hundred square metres in area, have rarely been the focus of ecological investigations. I sampled nine such islands in the central Exumas, Bahamas for arthropod species abundance and diversity using a combination of pitfall traps, pan traps and sticky traps. Three islands had no terrestrial vegetation, three islands contained only Sesuvium portulacastrum L., a salt-tolerant perennial that had been experimentally introduced 10 years ago, and three islands supported one or two naturally occurring plant species. A relatively diverse arthropod assemblage was discovered, including representatives of 10 different orders of Crustacea and Insecta. Land hermit crabs were the most abundant crustaceans, and dipterans were the most abundant and speciose insects. Two of the most common insects were previously undescribed species. Measures of arthropod species abundance and diversity were not significantly different for vegetated vs. non-vegetated islands. All 10 orders were present on bare islands, and nine of them were present on vegetated islands. Measures of arthropod species abundance and diversity were positively associated with island area, and negatively associated with distance from the nearest large island. Hypothesized food webs consist of several trophic levels and have strong allochthonous inputs. Tiny islands such as these hold insights into early successional processes and the base of insular food webs.
\end{abstract}

\section{Keywords}

Allochthonous, arthropod diversity, Bahamas, food webs, island biogeography.

\section{INTRODUCTION}

Oceanic islands represent excellent model systems for the study of many ecological patterns and processes, such as population persistence and turnover (Schoener, 1991; Morrison, 2002a, 2003; Schoener et al., 2003), food web ecology (Schoener, 1989; Polis \& Winemiller, 1996; Polis et al., 2004), succession (Bush \& Whittaker, 1991; Thornton, 1996) and resistance and resilience of populations to disturbance (Whittaker, 1995; Spiller et al., 1998; Schoener et al., 2001, 2004). Although many studies have addressed various ecological questions on oceanic islands, few investigators have focused on very small islands (on the order of a few hundred square metres in area). Such islands may be overlooked because they appear to harbour few or no terrestrial species, or because they are difficult to access by boat (i.e. no protected harbour). Very small islands, however, represent some of the simplest and least disturbed (by humans) ecosystems on the planet. These islands hold insights into early successional processes and the base of insular food webs.

The Bahamas Archipelago contains hundreds of islands, many are no more than mere 'rocks' (i.e. very small islands composed of marine limestone with little or no terrestrial vegetation).
Many of these are found in the Exuma Cays, an island chain stretching $150 \mathrm{~km}$ across the central Bahamas. I conducted arthropod surveys on nine very small islands $\left(75-1739 \mathrm{~m}^{2}\right)$ in this region. Three islands had no terrestrial vegetation, three islands supported a single plant species (Sesuvium portulacastrum L.) experimentally introduced 10 years ago, and three islands naturally supported one or two plant species.

The following questions were addressed: (1) What are the arthropod species abundances and diversities on these tiny islands? (2) How do arthropod species abundances and diversities vary with the presence or absence of terrestrial plant species? (3) Are standard island variables (i.e. area, distance and elevation) good predictors of arthropod species abundance and diversity on tiny islands? and (4) What is the basic structure of food webs on these islands?

\section{METHODS}

\section{Island characteristics and sampling techniques}

The islands studied lie in the central Exuma Cays, near Staniel Cay (see Morrison, 1997 for a map). All small islands sampled were composed entirely of marine limestone, and lie near larger 
Table 1 Physical attributes and measures of arthropod diversity and relative abundance on all islands sampled

\begin{tabular}{|c|c|c|c|c|c|c|c|c|}
\hline $\begin{array}{l}\text { Total } \\
\text { area } \\
\left(\mathrm{m}^{2}\right)\end{array}$ & $\begin{array}{l}\text { Vegetated } \\
\text { area } \\
\left(\mathrm{m}^{2}\right)\end{array}$ & $\begin{array}{l}\text { Distance } \\
(\mathrm{m})\end{array}$ & $\begin{array}{l}\text { Elevation } \\
(\mathrm{m})\end{array}$ & $\begin{array}{l}\text { No. of } \\
\text { orders }\end{array}$ & $\begin{array}{l}\text { No. of } \\
\text { orders } \\
\text { (- Crustacea) }\end{array}$ & $\begin{array}{l}\text { No. of } \\
\text { morpho- } \\
\text { species }\end{array}$ & $\begin{array}{l}\text { No. of } \\
\text { individuals }\end{array}$ & $\begin{array}{l}\text { No. of } \\
\text { individuals } \\
\text { (- Crustacea) }\end{array}$ \\
\hline \multicolumn{9}{|c|}{ Islands with no vegetation* } \\
\hline 99 & 0 & 763 & 1.37 & 5 & 3 & 4 & 145 & 132 \\
\hline 202 & 0 & 506 & 1.27 & 6 & 5 & 5 & 479 & 469 \\
\hline 89 & 0 & 1475 & 1.30 & 5 & 3 & 6 & 70 & 60 \\
\hline \multicolumn{9}{|c|}{ Islands with Sesuvium portulacastrum only* } \\
\hline 75 & 5.0 & 1025 & 1.32 & 5 & 3 & 4 & 143 & 98 \\
\hline 88 & 5.3 & 688 & 1.45 & 7 & 6 & 6 & 187 & 87 \\
\hline 203 & 4.2 & 156 & 1.19 & 7 & 7 & 9 & 467 & 352 \\
\hline \multicolumn{9}{|c|}{ Islands with natural vegetation $\dagger$} \\
\hline 176 & 21.3 & 250 & 1.24 & 5 & 4 & 4 & 133 & 56 \\
\hline 441 & 3.3 & 1200 & 1.32 & 5 & 4 & 4 & 164 & 41 \\
\hline 1739 & 8.3 & 774 & 1.32 & 6 & 4 & 4 & 64 & 13 \\
\hline
\end{tabular}

${ }^{*}$ Cumulative data from December 2002 and May 2003.

$\dagger$ Data from May 2003 only.

islands in the chain (see Schoener, 1991 for the distribution of island sizes in this region). Six small islands were sampled for arthropods during December 2002. Three islands contained no terrestrial vegetation, and three islands contained only S. portulacastrum, a salt-tolerant perennial that had been experimentally introduced 10 years ago (see Morrison, 1997, 2003). The latter three islands contained no vegetation before the introduction of $S$. portulacastrum.

Three sampling methods were employed: (1) pitfall traps, (2) pan traps, and (3) sticky traps. Pitfall traps were clear plastic vials ( $2.2 \mathrm{~cm}$ diametre, $5.2 \mathrm{~cm}$ deep) dug into pockets of soil so that the lip was flush with the soil surface. To prevent arthropods from escaping, pitfalls contained water with a small amount of detergent to break the surface tension. Pan traps were yellow plastic bowls ( $16 \mathrm{~cm}$ diametre, $4 \mathrm{~cm}$ deep) placed in depressions on the rocky surface of the islands. Pan traps also contained a soapy water solution. Sticky traps were sheets of clear plastic $(28 \times 21.5 \mathrm{~cm})$ coated with Tanglefoot ${ }^{\circledR}$ adhesive on both sides. Traps were suspended with monofilament line c. $20-30 \mathrm{~cm}$ above the surface of the rocks. On each island, four pitfall traps, five pan traps, and three sticky traps were left out for $24 \mathrm{~h}$, over 11-12 December. (On many islands, the small size of the island precluded the use of larger numbers of traps.) All islands were sampled over the same period so that climatic variation would not bias the results.

The same six islands were sampled for arthropods again in May 2003. Three additional islands that contained terrestrial vegetation (which had not been introduced deliberately) were also sampled in May 2003. Four pitfall traps and five pan traps were employed on each of all nine islands, as described above, over 15-16 May. Sticky traps were not used, because identification of specimens was problematic after they were covered with Tanglefoot ${ }^{\circledR}$ adhesive. Moreover, the December 2002 samples revealed that many of the taxa caught in sticky traps were also found in pan traps.
Sticky traps were examined in the field, and the order and the body length of specimens were recorded. The contents of pan traps and pitfall traps were examined under a microscope, and specimens were identified at least to order, and usually beyond. All insect specimens with the exception of Collembola were sorted as morphospecies, except those caught in sticky traps. Reference specimens have been deposited in the Florida State Collection of Arthropods in Gainesville, FL.

The islands with no terrestrial vegetation fell within a similar range of area, distance and elevation compared to the three islands containing only S. portulacastrum (Table 1). The islands containing natural vegetation fell within a similar range of distance and elevation, but two of the three were larger than any other islands. This was unavoidable because most vegetated islands in the region are larger than the islands without vegetation (Morrison, 1997). The vegetated areas of the islands with natural vegetation, however, were all small and fell within a relatively narrow range $\left(3.3-21.3 \mathrm{~m}^{2}\right)$. All three islands with natural vegetation contained Rhachicallis americana (Jacq.) O. Ktze. (seaside rock shrub), a small, woody shrub. One island contained a second species, Conocarpus erectus L. (buttonwood or gray mangrove), which grows as a shrub or tree.

\section{Statistical analyses}

Statistical comparisons were made with five abundance and diversity variables: (1) number of arthropod orders, (2) number of insect orders, (3) number of morphospecies (less the Crustacea and the Collembola), (4) number of arthropod individuals, and (5) number of insect individuals. Each variable was individually compared for islands without vegetation vs. islands with $S$. portulacastrum by two-tailed $t$-tests. Cumulative data from December 2002 and May 2003 were used in these tests. Each variable was also individually compared by one-way 
ANOVAs for islands without vegetation, islands with $S$. portulacastrum and islands naturally vegetated. Data from May 2003 only were used in these tests. For the four most abundant orders (Decapoda, Diptera, Collembola and Coleoptera), abundances of each order were compared for bare islands vs. islands with $S$. portulacastrum by two-tailed $t$-tests, using cumulative data from both seasons.

All five measures of abundance and diversity were individually entered in simple linear regressions as response variables against the explanatory variables island area, distance and elevation. The six islands sampled twice were included in the regressions because more complete data were available. Area was the two-dimensional surface of the island above the mean high tide mark. Distance was measured to the nearest mainland island, defined as islands $>46,580 \mathrm{~m}^{2}$, which reflects a natural discontinuity in the distribution of island areas in the region (Schoener, 1987). Elevation was measured as the vertical distance from the mean high tide mark to the highest point of the island. Area and distance were log-transformed to normalize the distributions before regression analyses. The small sample size precluded the use of multiple regression techniques. STATVIEW 5.0.1 (SAS Institute, 1999) was used for all analyses. When multiple comparisons were made within the same data set, the sequential Bonferroni method was used to control the type I error rate (Rice, 1989).

\section{RESULTS}

\section{Arthropod abundance and diversity}

Over 2000 specimens were sampled on all nine islands in both seasons (Table 2). Representatives of 10 orders were present on these small islands. Decapods and dipterans were the most

Table 2 Arthropod orders found on small islands. Incidence, number of islands (out of nine) on which the indicated order was found; Abundance, total number of individuals of each order summed over all islands; Relative abundance, proportion of total individuals represented by the indicated order. Data are cumulative over all islands, all sampling methods, and both sample periods

\begin{tabular}{llrl}
\hline Order & Incidence & Abundance & Relative abundance \\
\hline Crustacea & & & \\
Decapoda & 9 & 553 & 0.28 \\
Amphipoda & 3 & 4 & $<0.01$ \\
Isopoda & 2 & 8 & $<0.01$ \\
Insecta & & & \\
Diptera & 9 & 1230 & 0.61 \\
Collembola & 8 & 103 & 0.05 \\
Coleoptera & 8 & 59 & 0.03 \\
Hymenoptera & 5 & 32 & 0.02 \\
Orthoptera & 3 & 5 & $<0.01$ \\
Lepidoptera & 3 & 4 & $<0.01$ \\
Aranaeae & 2 & 3 & $<0.01$ \\
\hline
\end{tabular}

abundant crustaceans and insects, respectively, and together accounted for $89 \%$ of all individuals. Collembolans, coleopterans and hymenopterans were relatively common, occurring on the majority of the islands, while the remaining five orders were rare (each comprising $<0.01 \%$ of all individuals).

All decapods were land hermit crabs, Coenobita clypeatus (Herbst). This is the only land hermit crab in the Bahamas (Hartnoll, 1988), and is very common in this archipelago, occurring on almost all small islands (Morrison, 2002b). Two common shore crabs, Pachygrapsus transversus Gibbes (Grapsidae), were also caught, but not included in the data as the collection methods were not well suited for capturing this species. Moreover, Pachygrapsus spp. are residents of the intertidal zone and exhibit limited terrestrial adaptations.

The Diptera was the most abundant taxa, comprising $61 \%$ of all arthropods and $86 \%$ of the Insecta (Table 2). At least 11 different dipteran species were present (not all specimens caught in sticky traps could be accurately determined as morphospecies; Table 3). One species of Dasyhelea (Ceratapogonidae), representing a new species (Grogan \& Wieners, 2006), accounted for $>92 \%$ of all identified dipterans. Dipterans of this size range (c. $1 \mathrm{~mm}$ long) accounted for $94.4 \%$ (488 of 517) of all dipterans caught in sticky traps, and it is assumed that this same undescribed species accounted for the majority of 1-mm long dipterans in sticky traps.

The adult Coleoptera were represented by a single, new species (Skelley, 2005) in the Limnichidae (minute marsh-loving beetles). One larva of an unknown, although much larger species of Coleoptera was also present on one island.

Most of the Hymenoptera (30 of 32) were ants, Brachymyrmex obscurior Forel (Formicidae), captured in pitfall traps on all three islands with natural vegetation, but no others. Brachymyrmex obscurior is the most common ant in this archipelago, present on almost all islands with vegetation, but never present on islands lacking vegetation (Morrison, 1998). The other two hymenopterans were caught in sticky traps, and appeared to be parasitoid wasps.

All spiders were juveniles. Two were determined to be in the family Linyphiidae. One of the lepidopterans was Achyra rantalis Guenee (Crambidae), a common herbivore of S. portulacastrum (D. A. Spiller, pers. comm.). The other three lepidopterans (captured in sticky traps) were damaged and not identified beyond order. Of five orthopterans, only one was an adult - a female ground cricket (subfamily Nemobiinae). The genus represented is not known from the United States, and may be undescribed (T. J. Walker, pers. comm.). One female nymph and three younger nymphs were apparently all of the same species.

\section{Insular patterns}

Overall, islands with $S$. portulacastrum tended to have slightly higher numbers of taxa (all orders, insect orders only and morphospecies) than bare islands (Table 1), although no comparisons of any of the abundance or diversity variables were significant ( $t$-tests, all $P>0.05$ ). When all three sets of islands (no 
Table 3 Taxonomy of insects captured in pan and pitfall traps on the small islands sampled (does not include sticky trap catches)

\begin{tabular}{|c|c|c|c|c|}
\hline Order $^{*}$ & Family (Subfamily) & Genus & Species & Total no. $\dagger$ \\
\hline Araneae & Linyphiidae & & & $3 \ddagger$ \\
\hline \multirow[t]{2}{*}{ Coleoptera } & Limnichidae & Mexico & New species $\S$ & $46 \ddagger$ \\
\hline & Unknown (larva) & & & 1 \\
\hline \multirow[t]{11}{*}{ Diptera } & Ceratapogonidae & Dasyhelea & New species $\$$ & 658 \\
\hline & Ephydridae & Glenanthe & & 25 \\
\hline & Ephydridae & Paraglenanthe & & 8 \\
\hline & Chironomidae (Orthocladiinae) & Clunio & marshalli & 7 \\
\hline & Cecidomyiidae & Genus A & & 5 \\
\hline & Chironomidae & Mesosmittia & & 4 \\
\hline & near Chlopopidae & & & 4 \\
\hline & Cecidomyiidae & Genus B & & 5 \\
\hline & Chironomidae (Chironominae) & Chironomus & & 1 \\
\hline & Sciaridae & Phytosciara & & 1 \\
\hline & Dolichopodidae & & & 1 \\
\hline Hymenoptera & Formicidae (Formicinae) & Brachymyrmex & obscurior & 30 \\
\hline \multirow[t]{2}{*}{ Lepidoptera } & Crambidae (Pyraustinae) & Achyra & rantalis & 1 \\
\hline & Unknown (damaged specimen) & & & 1 \\
\hline Orthoptera & Gryllidae (Nemobinae) & New genus? & & $5 \ddagger$ \\
\hline
\end{tabular}

*Excludes collembolans, which were not identified beyond order and were not enumerated.

$\dagger$ Cumulative number of individuals from all islands, including the December 2002 and the May 2003 samplings.

\#Including juveniles assumed to be of the same taxa.

\$Descriptions in press (Skelley, 2005; Grogan \& Wieners, 2006).

TThis material has been examined by taxonomists and does not match any known genus descriptions. Because few specimens were available (most were nymphs), further determination was not pursued.

vegetation, $S$. portulacastrum introductions and natural vegetation) were compared (based on May 2003 data), islands with natural vegetation had slightly higher numbers of taxa. The only significant comparison, however, was for insect orders (one-way ANova, $F=6.0 ; P=0.037$; d.f. $=2,6)$. This comparison was not significant after correction for multiple comparisons, however.

Table 4 Numbers of individuals of all arthropod orders (mean \pm SD) found on islands with Sesuvium portulacastrum compared to islands with no vegetation. Numbers are summed over both sampling periods

\begin{tabular}{lcc}
\hline Order & S. portulacastrum islands & Bare islands \\
\hline Crustacea & & \\
Decapoda & $84.0 \pm 40.4$ & $10.0 \pm 1.0$ \\
Amphipoda & 0 & $0.3 \pm 0.6$ \\
Isopoda & $2.3 \pm 4.0$ & $0.3 \pm 0.6$ \\
Insecta & & \\
Diptera & $156.7 \pm 150.2$ & $223.7 \pm 273.5$ \\
Collembola & $12.0 \pm 5.6$ & $20.3 \pm 18.3$ \\
Coleoptera & $9.0 \pm 6.1$ & $8.0 \pm 7.2$ \\
Hymenoptera & $0.3 \pm 0.6$ & $0.3 \pm 0.6$ \\
Orthoptera & $1.3 \pm 1.5$ & $0.3 \pm 0.6$ \\
Lepidoptera & $0.3 \pm 0.6$ & $0.7 \pm 1.2$ \\
Aranaeae & $0.3 \pm 0.6$ & $0.7 \pm 1.2$ \\
\hline
\end{tabular}

Overall, fewer unique morphospecies were found on bare islands compared to $S$. portulacastrum islands. Nineteen different morphospecies were identified from the six islands sampled in December and May. Of these, 10 were found on at least one of the islands lacking vegetation, whereas 13 were found on the islands with S. portulacastrum.

Of the four most abundant orders (Decapoda, Diptera, Collembola and Coleoptera), only one had significantly different abundances between bare islands and islands with S. portulacastrum: hermit crabs were significantly more abundant on $S$. portulacastrum islands than on bare islands ( $84 \pm 41$ vs. $10 \pm 1$ [mean $\pm S D$ ], respectively, $t=3.168, P=0.0339$, d.f. $=4$; two-tailed $t$-tests; Table 4). Again, this comparison was not significant after correction for multiple comparisons.

In simple linear regressions, all response variables were positively correlated with island area, and negatively correlated with distance (Table 5). Island area was a significant explanatory variable for number of all individuals and number of insect individuals. Variation in distance explained much of the variation in number of insect orders and number of individuals, although these relationships were not significant after correction for multiple comparisons. Island area was negatively correlated with island distance $\left(R^{2}=0.65\right)$, obscuring to some degree the independent effects of these two explanatory variables; this correlation was only marginally significant $(P=0.0514)$, however. Elevation was not significant in any comparisons (all $P \gg 0.05)$. 
Table 5 Simple linear regressions of five response variables against the explanatory variables island area and distance. All response variables were positively correlated with island area, and negatively correlated with distance

\begin{tabular}{llrl}
\hline Response variable & $R^{2}$ & $F$ & $P$ \\
\hline Regressed against log(area) & & & \\
No. of orders & 0.269 & 1.47 & 0.2921 \\
No. of insect orders & 0.421 & 2.91 & 0.1633 \\
No. of morphospecies & 0.306 & 1.76 & 0.2550 \\
No. of individuals & 0.907 & 39.00 & $0.0034^{*}$ \\
No. of insect individuals & 0.911 & 40.81 & $0.0031^{*}$ \\
Regressed against log(distance) & & & \\
No. of orders & 0.555 & 4.99 & 0.0893 \\
No. of insect orders & 0.713 & 9.96 & 0.0343 \\
No. of morphospecies & 0.545 & 4.78 & 0.0940 \\
No. of individuals & 0.717 & 10.15 & 0.0334 \\
No. of insect individuals & 0.499 & 3.99 & 0.1165 \\
& & & \\
\hline
\end{tabular}

${ }^{*}$ Significant by the sequential Bonferroni method of multiple comparisons (Rice, 1989).

\section{DISCUSSION}

From a distance, the islands sampled appear to be mere rocks projecting just above the high tide line, with little or no terrestrial vegetation. Only two of the naturally vegetated islands were much larger than $200 \mathrm{~m}^{2}$. Most are so small and low-lying that their entire surface is wet from breaking waves and salt spray at high tide. In fact, one pitfall trap was inadvertently placed below the high tide line on an island, and the next day was filled with seawater and thimble jellyfish, Linuche unguiculata (Schwartz)! Yet a surprising diversity of arthropod life was found on these tiny islands.

Although islands with vegetation tended to have slightly higher arthropod diversities than bare islands, no statistical tests were significant after correction for multiple comparisons. Because the sample sizes were small, the tests had low power. Yet all 10 orders of arthropods were present on bare islands, and nine of the 10 were present on vegetated islands, indicating that all could survive on islands lacking terrestrial vegetation. This strongly suggests that the base of food webs on these small islands is marine-derived (see below).

\section{Effects of area and distance}

The generalized positive correlations of the abundance and diversity variables with area, and negative correlations with distance, are in accord with basic island biogeographical theory (MacArthur \& Wilson, 1967). The mechanisms underlying these patterns, however, may differ somewhat from those expected on larger islands. For species that are able to complete their life cycles and reproduce on the islands, island area may affect diversity in a similar manner as it does for larger islands (e.g. Connor \& McCoy, 1979). For species that disperse to the islands from elsewhere, island area may affect species diversity through the 'target effect' (Gilpin \& Diamond, 1976), with larger islands representing larger targets. A potential third mechanism, unique to very small islands, is that during storms or extreme high tides, breaking waves may render much or all of the island uninhabitable (and potentially lethal) to many species or life stages.

Distance may operate as a barrier in the classic sense for species that disperse from elsewhere. Increasing distance, however, is also usually correlated with increasing water depth and greater exposure to open ocean, which could result in more intense wave action during storms and thus a more hostile environment for many terrestrial species or life stages. Elevation may not have been a significant explanatory variable because the islands spanned only a narrow range of elevations (ranging from $1.19 \mathrm{~m}$ to $1.60 \mathrm{~m}$, for all nine islands).

\section{Colonization of small islands}

Some of the species found on the small islands could have originated on larger, neighbouring islands and dispersed to the small islands. Other species, however, may be residents of these small islands, completing their entire life cycles there. In theory, all Diptera, Coleoptera, Hymenoptera and Lepidoptera found could disperse to these small islands by active flight. The spiders could arrive by ballooning. Larvae of the land hermit crab, C. clypeatus, have a marine planktonic development stage (Adiyodi, 1988). The adult cricket did not have functional wings, and thus these Nemobinae would apparently have to rely on rafting, or passive dispersal attached to some other organisms. Collembola may disperse over water barriers passively by wind, rafting or be transported by birds or humans. Wind may be particularly important, and Collembola are often components of aerial plankton. Collembola were among the earliest colonizers of a small island that erupted from the sea near Krakatau (Hopkin, 1997). There are no indications that the small islands of this study are visited by anyone except the ecologists who study them, so human-induced dispersal is unlikely for any group.

Almost all spiders and crickets were juveniles. This could be interpreted by indicating that these taxa may disperse relatively frequently to such small islands, but only rarely survive to the adult stage and reproduce. This could be the case for spiders, which may balloon easily among islands, but probably not for ground crickets, which apparently rely on rafting to colonize new islands (which appears to be rare in this archipelago). An alternate explanation is that the pitfalls and pan traps employed were not as effective as capturing adults as juvenile stages. This is particularly likely for the pitfall traps, given the relatively small size of opening.

The most abundant species present, a previously undescribed species of Dasyhelea, could potentially complete its life cycle on these tiny islands. Adult ceratapogonids generally do not travel far from the place where the larvae occur (Borror et al., 1989), and members of the subfamily Dasyheleinae are often found in habitats such as rock pools (Downes \& Wirth, 1981). Adults of the Dasyhelea sp. found may be able to reproduce without feeding if enough food resources could be obtained in the larval stage 
(W. L. Grogan, Jr., pers. comm.). Alternatively, adults of this species may feed at nearby islands containing vegetation (adult Dasyhelea feed only on nectar from flowers or honeydew from Homoptera), and then disperse to the small islands for mating. These small islands may serve as 'swarming markers', where males aggregate and await females (W. L. Grogan, Jr., pers. comm.). It is unknown whether the eggs would be deposited on the small islands or the larger islands.

Of the three chironomid genera collected, Clunio is exclusively intertidal, and Chironomus species frequently occur on marine rocky shores (Armitage et al., 1995). Interestingly, Mesosmittia has no known association with the marine zone, although the larval habits of this genus are not well known (P. S. Cranston, pers. comm.). Only male Clunio were found on the small islands. The females of Clunio are flightless (Armitage et al., 1995), suggesting that, if females are present, this species must be able to reproduce on the small islands, although males may be able to disperse among islands. It is possible that only wayward males exist on these islands, although the trapping methods used were strongly biased toward flying (or jumping) organisms.

\section{Allochthonous vs. autochthonous energy sources}

An important question in food web ecology concerns the relative proportion of allochthonous vs. autochthonous inputs (Polis \& Winemiller, 1996; Polis et al., 2004). Some islands may derive relatively large amounts of energy from the marine environment, either directly from material washing up on shore or indirectly from seabirds; this has been particularly well documented for desert islands in the Gulf of California (Polis \& Hurd, 1995, 1996; Anderson \& Polis, 1998; Barrett et al., 2003, 2005). Most rocky limestone islands in the central Exumas do not appear to have the shore drift or large nesting seabird colonies that are present on islands in the Gulf of California, and it has been assumed that allochthonous inputs do not play a major role in insular food webs in the Bahamas (e.g. Schoener, 1989). Recent work using stable isotope analyses, however, has revealed evidence for the importance of marine subsidies to Bahamian food webs (D. A.
Spiller and A. L. W. Sears, unpublished manuscript). Marine subsidies are likely to become relatively more important as the ratio of shoreline to island area increases (i.e. as islands become smaller; Polis \& Hurd, 1996). The results presented here demonstrate the importance of allochthonous inputs in an extreme case: tiny islands in the complete absence of terrestrial vegetation.

Few investigators have studied terrestrial arthropods on islands lacking terrestrial vegetation, but the results are often surprising. Terrestrial arthropods (and even a gekkonid lizard) have been reported from islands in the Caribbean and the Great Barrier Reef that lacked terrestrial vegetation (Heatwole, 1971; Heatwole et al., 1981). In both cases, seabirds that contributed carrion and guano to the islands apparently provided energy indirectly from the marine environment.

The small islands sampled in the Exumas revealed little evidence of allochthonous input from seabirds. Occasionally a partial fish skeleton and a small amount of excrement from an osprey was present, but no seabirds nested on these islands. Although the sides of the islands are generally steep, the islands are all low, potentially allowing marine material to be deposited on top of the islands at high tide.

\section{Food webs}

These tiny islands, devoid of terrestrial vegetation, may support relatively diverse food webs with several trophic levels (Fig. 1). Linyphiid spiders are predators, weaving sheet-like webs close to the ground. Collembolans often make up a large proportion of their diet (G. B. Edwards, pers. comm.). In general, the Nemobiinae are omnivorous (Gangwere, 1961), and ground crickets on small islands such as these may feed on marine algae (T. J. Walker, pers. comm.). Limnichid beetles usually live near water, including the intertidal zone, and most species are thought to be herbivorous (Spilman, 1972; Woolridge, 1988; Shepard, 2002). This species of limnichid present may also be feeding on marine algae on these islands (P. E. Skelley, pers. comm.).

The larvae of the most common dipteran present, Dasyhelea, feed on algae and bacteria (W. L. Grogan, Jr., pers. comm.). Adult

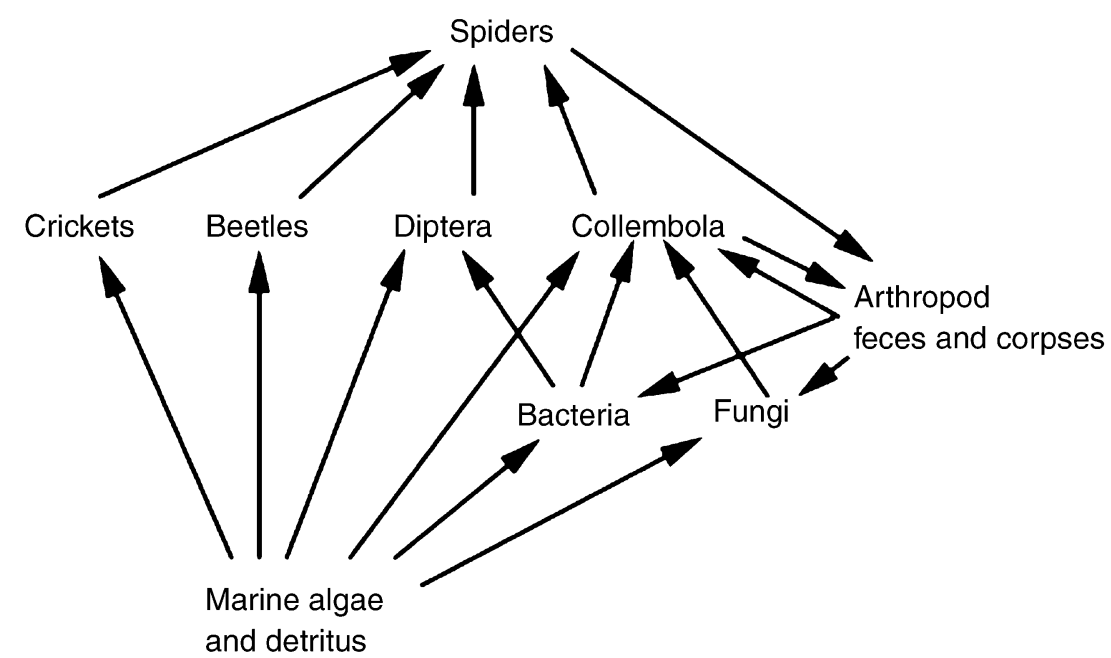

Figure 1 Hypothetical food web of tiny Bahamian islands. Not all potential links are shown, and some of the less common taxa are not included. The Crustacea are generalist scavengers and may feed on many of the indicated taxa. 
Dasyhelea have vestigial mandibles and do not take blood meals as do other members of this family. Chironomid larvae are generally microphagous, feeding on detritous and small plants and animals (Downes \& Wirth, 1981). Collembola feed on decaying plant material, fungi, bacteria, arthropod faeces and algae (Borror et al., 1989; Hopkin, 1997).

Land hermit crabs, C. clypeatus (which accounted for all of the decapods), are generalist scavengers and feed on a variety of food items, including carrion and insects (Dunham \& Gilchrist, 1988). Isopods are generally omnivorous, and amphipods are usually scavengers or carnivores (Schram, 1986).

\section{Implications}

This study raises many questions, such as whether the species found on these small islands are able to complete their entire life cycles there, or whether they disperse from larger islands. If they originate elsewhere, do the small islands simply represent 'sinks', in which individuals arrive randomly and fail to reproduce? Or do the small islands serve an important function in the biology of some groups (e.g. swarming markers for ceratapogonids)? Do all species found on the small islands also occur on larger islands in the archipelago, or are some species 'small island specialists'? Additional investigations on such small islands would likely be rewarded with many interesting discoveries.

\section{ACKNOWLEDGEMENTS}

This work was supported by a National Geographic Society grant (\#7447-03) to the author, and an NSF grant to D. A. Spiller. P. Cranston, L. R. Davis, Jr., G. B. Edwards, W. L. Grogan, Jr., P. E. Skelley, G. J. Steck, and T. J. Walker identified specimens. W. B. Anderson, D. A. Spiller, T. W. Schoener, and D. A. Wait provided helpful comments on a previous version of this manuscript.

\section{REFERENCES}

Adiyodi, R.G. (1988) Reproduction and development. Biology of the land crabs (ed. by W.W. Burggren and B.R. McMahon), pp. 139-185. Cambridge University Press, Cambridge.

Anderson, W.B. \& Polis, G.A. (1998) Marine subsidies of island communities in the Gulf of California: evidence from stable carbon and nitrogen isotopes. Oikos, 81, 75-80.

Armitage, P.D., Cranston, P.S. \& Pinder, L.C.V., eds. (1995) The Chironomidae: biology and ecology of non-biting midges. Chapman \& Hall, London.

Barrett, K., Anderson, W.B., Wait, D.A., Grismer, L.L., Polis, G.A. \& Rose, M.D. (2005) Marine subsidies alter the diet and abundance of insular and coastal lizard populations. Oikos, 109, 145-153.

Barrett, K., Wait, D.A. \& Anderson, W.B. (2003) Small island biogeography in the Gulf of California: lizards, the subsidized island biogeography hypothesis, and the small island effect. Journal of Biogeography, 30, 1575-1581.

Borror, D.J., Triplehorn, C.A. \& Johnson, N.F. (1989) An introduction to the study of insects. Saunders College Publishing, Philadelphia, PA.

Bush, M.B. \& Whittaker, R.J. (1991) Krakatau: colonization patterns and hierarchies. Journal of Biogeography, 18, 341-356.

Connor, E.F. \& McCoy, E.D. (1979) The statistics and biology of the species-area relationship. The American Naturalist, 113, 791-833.

Downes, J.A. \& Wirth, W.W. (1981) Ceratopogonidae. Manual of Nearctic Diptera (ed. by J.F. McAlpine, B.V. Peterson, G.E. Shewell, H.J. Tesky, J.R. Vockeroth and D.M. Wood). Ottawa, Research Branch, Agriculture Canada. Monograph 27, Vol. 1.

Dunham, D.D. \& Gilchrist, S.L. (1988) Behavior. Biology of the land crabs (ed. by W.W. Burggren and B.R. McMahon), pp. 97-138. Cambridge University Press, Cambridge.

Gangwere, S.K. (1961) A monograph on food selection in Orthoptera. Transactions of the American Entomological Society, 87, 67-230.

Gilpin, M.E. \& Diamond, J.M. (1976) Calculation of immigration and extinction curves from the species-area-distance relation. Proceedings of the National Academy of Sciences, USA, 73, 4130-4134.

Grogan, W.L. Jr \& Wieners, J.A. (2006) A new species of the biting midge genus Dasyhelea Kieffer from the Bahamas (Diptera: Ceratopogonidae). Proceedings of the Entomological Society of Washington (in press).

Hartnoll, R.G. (1988) Evolution, systematics, and geographical distribution. Biology of land crabs (ed. by W.W. Burggren and B.R. McMahon), pp. 6-54. Cambridge University Press, Cambridge.

Heatwole, H. (1971) Marine-dependent terrestrial biotic communities on some cays in the Coral Sea. Ecology, 52, 363-366.

Heatwole, H., Levins, R. \& Byer, M.D. (1981) Biogeography of the Puerto Rican Bank. Atoll Research Bulletin. The Smithosonian Institution.

Hopkin, S.P. (1997) Biology of the springtails (Insecta, Collembola). Oxford University Press, Oxford.

MacArthur, R.H. \& Wilson, E.O. (1967) The theory of island biogeography. Princeton University Press, Princeton.

Morrison, L.W. (1997) The insular biogeography of small Bahamian cays. Journal of Ecology, 85, 441-454.

Morrison, L.W. (1998) The spatiotemporal dynamics of insular ant metapopulations. Ecology, 79, 1135-1146.

Morrison, L.W. (2002a) Island biogeography and metapopulation dynamics of Bahamian ants. Journal of Biogeography, 29, $387-$ 394.

Morrison, L.W. (2002b) Interspecific competition and coexistence between ants and land hermit crabs on small Bahamian islands. Acta Oecologica, 23, 223-229.

Morrison, L.W. (2003) Plant species persistence and turnover on small Bahamian cays. Oecologia, 136, 51-62.

Polis, G.A. \& Hurd, S.D. (1995) Extraordinarily high spider densities on islands: flow of energy from the marine to terrestrial food webs and the absence of predation. Proceedings of the National Academy of Sciences, USA, 92, 4382-4386.

Polis, G.A. \& Hurd, S.D. (1996) Linking marine and terrestrial food webs: allochthonous input from the ocean supports 
high secondary productivity on small islands and coastal land communities. American Naturalist, 147, 396-423.

Polis, G.A., Power, M.E. \& Huxel, G.R., eds. (2004) Food webs at the landscape level. University of Chicago Press, Chicago.

Polis, G.A. \& Winemiller, K.O., eds. (1996) Food webs: integration of patterns and dynamics. Chapman \& Hall, New York.

Rice, W.R. (1989) Analyzing tables of statistical tests. Evolution, 43, 223-225.

SAS Institute (1999) STATview 5.0.1. SAS Institute, Cary, North Carolina.

Schoener, T.W. (1987) Leaf pubescence in buttonwood: community variation in a putative defense against defoliation. Proceedings of the National Academy of Sciences, USA, 84, 7992-7995.

Schoener, T.W. (1989) Food webs from the small to the large. Ecology, 70, 1559-1589.

Schoener, T.W. (1991) Extinction and the nature of the metapopulation: a case study. Acta Oecologica, 12, 53-75.

Schoener, T.W., Clobert, J., Legendre, S. \& Spiller, D.A. (2003) Life-history models of extinction: a test with the island spiders. American Naturalist, 162, 558-573.

Schoener, T.W., Spiller, D.A. \& Losos, J.B. (2001) Natural restoration of the species-area relation for a lizard after a hurricane. Science, 294, 1525-1528.

Schoener, T.W., Spiller, D.A. \& Losos, J.B. (2004) Variable ecological effects of hurricanes: The importance of seasonal timing for survival of lizards on Bahamian islands. Proceedings of the National Academy of Sciences, USA, 101, 177-181.

Schram, F.R. (1986) Crustacea. Oxford University Press, Oxford. Shepard, W.D. (2002) Limichidae. American beetles. 2. Polyphaga: Scarabaeoidea through Curculionoidea (ed. by R.H. Arnett, Jr., M.C. Thomas, P.E. Skelley and J.H. Frank). CRC Press, Boca Raton, FL.

Skelley, P.E. (2005) A new species of Mexico Spilman from the Bahamas (Coleoptera: Limnichidae: Thaumastodinae). Insecta Mundi (in press).

Spiller, D.A., Losos, J.B. \& Schoener, T.W. (1998) Impact of a catastrophic hurricane on island populations. Science, 281, 695-697.

Spilman, T.J. (1972) A new genus and species of jumping shore beetle from Mexico. The Pan-Pacific Entomologist, 48, 108-115.

Thornton, I.W.B. (1996) Krakatau - the destruction and reassembly of an island ecosystem. Harvard University Press, Cambridge, MA.

Whittaker, R.J. (1995) Disturbed island ecology. Trends in Ecology and Evolution, 10, 421-425.

Woolridge, D.P. (1988) Martinius temporalis, a new species from Ecuador (Coleoptera: Limnichidae: Thaumastodinae). Journal of the New York Entomological Society, 96, 314-315. 